\title{
IMPLEMENTASI SUPERVISI PENDIDIKAN \\ DALAM MENINGKATKAN PROSES \\ PEMBELAJARAN DI MIN SUKADAMAI KOTA \\ BANDA ACEH
}

\author{
Ela Firda Siska \\ elafirdasiska@gmail.com
}

\begin{abstract}
Abstrak
Sebagai supervisor di sebuah sekolah, seorang kepala sekolah harus mampu melakukan pengawasan dan pengendalian untuk meningkatkan kinerja guru. Kegiatan pengawasan dan pengendalian merupakan tindakan preventiv atau pencegah agar guru lebih berhati-hati dan tidak melakukan penyimpangan dalam melaksanakan tugasnya sebagai pendidik. Penelitian ini mengungkap pelaksanaan supervisi yang dilakukan kepalas sekolah MIN Sukadamai Kota Banda Aceh terhadap kinerja guru. Setelah dilakukan penelitian ini, didapatkan hasil sebagai berikut: 1) focus kegiatan supervise yang dilakukan kepala sekolah dapat di identifikasikan ke dalam dua hal yaitu kegiatan supervise yang menyangkut administrasi guru dan kegiatan proses belajar mengajar. 2) kegiatan supervise sangat membantu guru dalam menyelesaikan masalah-masalah pendidikan yang dihadapi guru saat melakukan kegiatan pembelajaran, dan memotivasi

guru untuk selalu meningkatkan pengetahuannya menjadi guru professional. 3) tumpang tindih kegiatan dan dana operasional menjadi hambatan kepala sekolah dalam melakukan supervise.
\end{abstract}

\section{Kata Kunci: Supervisi, Kepala Sekolah, Guru}

\section{PENDAHULUAN}

Guru memiliki kemampuan untuk berkreasi dan meningkatkan kinerjanya. Namun terdapat berbagai factor untuk menghambat pengembangan potensinya secara optimal, baik untuk mengembangkan kemampuan guru itu sendiri dalam proses belajar mengajar, maupun sarana dan prasarana pendidikan. Karena hal tersebut dirasa sangat diperlunya supervise yang berkesinambungan dengan program yang terarah dan sistematis terhadap guru. Fungsi utama dari supervise pendidikan adalah memperbaiki situasi belajar mengajar di sekolah agar menjadi lebih baik lagi. Supervise terhadap proses belajar mengajar membantu guru melaksanakan tugasnya secara efektif. Dalam QS. Al-'Asr : 3 dijelaskan terkait supervise yaitu saling menasehati dalam kebenaran dan saling menasehati dalam kesabaran. Firman Allah tersebut memiliki pesan implisit 
bahwa saling menasehati dalam kebaikan dan kesabaran merupakan kunci dalam menyelenggarakan supervise pendidikan di sekolah untuk meningkatkan mutu pendidikan, perbaikan akhlak dan tata cara beretika serta pemberian motivasi guna mencapai mutu . kepala sekolah sebagai seorang supervisor harus mampu melakukanberbagai pengawasan dan pengendalian agar guru lebih berhati- hati dalam menjalankan tugasnya sebagai pendidik.

\section{PEMBAHASAN}

Pengertian Supervisi

Suryani (Suryani, 2016) Kata supervisi berasal dari bahasa Inggris yaitu supervision, terdiri atas dua kata, yaitu super dan vision yang mengandung pengertian melihat dengan sangat teliti pekerjaan secara keseluruhan. Orang yang melakukan supervisi yang disebut supervisor. Suharsimi menjelaskan, bahwa supervisi terdiri dari dua kata "super" dan "vision" yang berarti "melihat" maka secara keseluruhan supervisi diartikan sebagai melihat dari atas. Dengan pengertian itulah supervisi dikatakan sebagai kegiatan yang dilakukan oleh kepala sekolah sebagai pejabat yang berkedudukan di atas lebih tinggi dari guru untuk melihat dengan teliti pekerjaan secara keseluruhan atau mengawasi pekerjaan guru. Terdapat tiga unsur dalam supervise pendidikan, yaitu:

1. Unsur proses pengarahan, bantuan atau pertolongan dari pihak atasan atau pihak yang lebih memahami.

2. Unsur guru-guru dan personalia sekolah lainnya yang berhubungan langsung dengan belajar mengajar para siswa sebagai pihak yang diberikan pertolongan.

3. Unsur proses belajar mengajar atau situasi belajar mengajar sebagai objek yang diperbaik

Sabandi (Sabandi, 2013) Perkembangan supervisi pendidikan berkembang seiring dengan perkembangan ilmu pengetahuan, teknologi, serta sosial ekonomi dan budaya masyarakat. Supervisi bergerak dari berbentuk inspeksi dimana otoritas lebih didominasi oleh supervisor, berkembang dalam bentuk kolaborasi antara supervisor dan guru bersama berinisiatif dan bertanggungjawab dalam meningkatkan kualitas pembelajaran, serta menumbuhkan budaya belajar pada guru untuk selalu meningkatkan kompetensinya 
Tujuan dan Peran Supervisi Pendidikan

Suryani (Suryani, 2016) Supervise bertujuan untuk membantun memperbaiki dan meningkatkan pengelolaan sekolah berkenaan dengan aspek kognitif, psikomotor, dan afektif sehingga tercapainya kondisi belajar dan mengajar sebaik-baiknya. Supervisi yang efektif tidak mampu merefleksikan multi tujuan. Supervise berhasil jika tidak mengesampingkan tujuan yang lain. Sehingga dapat dipahami bahwa tujuan dari supervisi adalah memperbaiki dan mengembangkan proses belajar mengajar secara total tidak hanya memperbaiki mutu mengajar guru namun juga mempebina pertumbuhan profesi guru dan termasuk fasilitas-fasilitas, pelayanan kepemimpinan dan terjalinnya hubungan baik dengan semua pihak yang terkait perbaikan dan peningkatan proses belajar mengajar di sekolah menjadi fungsi utama dalam supervisi.

Menurut Sabandi (Sabandi, 2013) Supervisor memegang peranan penting dalam meningkatkan kualitas guru agar dapat melaksanakan pembelajaran yang lebih berkualitas. Jabatan supervisor di sekolah meliputi kepala sekolah dan pengawas. Supervisi yang dilakukan oleh kepala sekolah diatur dalam Permen Diknas Nomor 13 Tahun 2007 tentang Standar Kepala Sekolah/Madrasah. Dimensi kompetensi supervisi kepala sekolah yang meliputi: (1) merencanakan program supervisi akademik dalam rangka peningkatan profesionalisme guru, (2) melaksanakan supervisi akademik terhadap guru dengan menggunakan pendekatan dan teknik supervisi yang tepat, dan (3) menindaklanjuti hasil supervisi akademik terhadap guru dalam rangka peningkatan profesionalisme guru.

\section{HASIL PENELITIAN}

Penyusunan Program Supervisi Pendidikan

Suryani (Suryani, 2016) Berdasarkan hasil penelitian di lapangan dapat diungkapkan bahwa penyusunan program supervisi pendidikan dilaksanakan oleh kepala sekolah. Dalam penyusunan program supervisi pendidikan kepala sekolah melibatkan wakil kepala dan guru-guru. Hal ini terbukti dari hasil wawancara dengan Nurasiah, Wakil Kepala Sekolah MIN Sukadamai Kota Banda Aceh mengatakan, bahwa "Kepala sekolah mengajak kami, guru-guru yang senior dalam penyusunan program 
supervisi pendidikan". Kepala MIN Sukadamai Kota Banda Aceh mengatakan, bahwa: "Penyusunan program supervisi pendidikan dibuat pada awal tahun ajaran. Hal ini dimaksudkan supaya program kegiatan supervisi dapat diintegrasikan dalam kegiatankegiatan sekolah secara komprehensif. Pelaksanaan supervisi pendidikan dilakukan setiap awal tahun pelajaran, setiap awal semester dan pada saat berlangsungnya kegiatan proses belajar mengajar. Fokus kegiatan supervisi yang dilakukan kepala sekolah dapat diidentifikasikan ke dalam dua hal yaitu; pertama, kegiatan supervisi yang menyangkut administrasi guru, dalam hal ini menyangkut semua persiapan yang harus dipersiap oleh seorang guru sebelum melakukan pembelajaran dan kedua, kegiatan supervisi yang menyangkut dengan kegiatan proses belajar mengajar." Selanjutnya kepala sekolah MIN Sukadamai Kota Banda Aceh, menjelaskan bahwa "Penyusunan program supervisi pendidikan dilaksanakan pada awal semester ganjil atau pada awal tahun ajaran, demikian juga pelaksanaan programnya. Sedangkan evaluasi program supervisi pendidikan dilakukan pada setiap akhir semester ganjil dan semester genap dengan tujuan dapat mengetahui sejauhmana pencapaian program supervisi yang telah dilaksanakan".Sehubungan dengan uraian di atas, hasil wawancara dengan guru-guru menyatakan bahwa mereka mengetahui kepala sekolah telah menyusun jadwal supervisi. Sebelum melaksanakan supervisi terhadap guru-guru sudah menyusun program terlebih dahulu, jika program tidak disusun terlebih dahulu dengan baik, maka pelaksanaannya tidak sesuai dengan apa yang diharapkan. Adapun program-program yang disusun mengenai jadwal kegiatannya terdiri dari tanggal dimulai pelaksanaannya sampai akhir, alat yang diperlukan, tujuan yang ingin dicapai, rancangan untuk pengembangan kemampuan profesianal guru, meningkatkan motivasi kerja guru dan bagai mana cara agar supervisi pendidikan dapat berjalan dengan baik. Kepala sekolah merencanakan pelaksanaan supervisi pendidikan terhadap guru-guru minimal satu kali, dan maksimal dua kali dalam setahun, yaitu satu kali pada semester ganjil dan satu kali pada semester genap. Jadwal pelaksanaannya pada awal dan akhir semester, baik semester ganjil maupun semester genap. Hal ini dilakukan untuk melihat perkembangan dan perubahan yang dilakukan guru dalam proses belajar mengajar.

\section{KESIMPULAN}


Dari hasil pembahasan di atas dapat disimpulkan bahwa: Pelaksanaan supervisi pendidikan dilakukan Kepala Sekolah MIN Sukadamai Kota Banda Aceh didahului dengan penyusunan program supervisi yang dipersiapkan pada awaltahun ajaran. Selanjutnya dilanjutkan denganpelaksanaannya yang dilakukan setiap awal semester dan akhir semester pada saat berlangsungnya kegiatan proses belajar mengajar untuk melihat keberhasilan sejauh mana program yang telah dipersiapkan dapat terealisasi. Fokus kegiatan supervisi yang dilakukan kepala sekolah dapat diidentifikasikan ke dalam dua hal yaitu; pertama kegiatan supervise yang menyangkut administrasi guru. Hal ini menyangkut semua persiapan yang harus dipersiapkan oleh seorang guru sebelum melakukan pembelajaran. Kedua, kegiatan supervisi yang menyangkut dengan kegiatan proses belajar mengajar. Program tahunan disusun dengan tujuan untuk meningkatkan kualitas pendidikan melalui penilaian dan pembinaan terhadap teknis dan administrasi pendidikan di sekolah, dan memberikan pedoman serta kejelasan bagi guru dalam rangka penyusunan program semester/program tahunan, dan dijabarkan berdasarkan hasil rapat guru tahun sebelumnya. Kepala sekolah melakukan supervisi terhadap semua komponen pendidikan sekolah. Pelaksanaan supervise pendidikan yang dilakukan oleh kepala sekolah lebih menekankan pada pembinaan terhadap kemampuan guru dalam mengelola pembelajaran. Kaitan supervisi pendidikan yang dilakukan kepala sekolah terhadap proses belajar mengajar guru pada MIN Sukadamai Kota Banda Aceh adalah sangat membantu bagi guru dalam memecahkan masalahmasalah pendidikan yang dihadapi guru pada saat melakukan pembelajaran, serta dapat memberikan motivasi bagi guru agar selalu meningkatkan pengetahuan untuk menjadi guru yang professional dalam melaksanakan pembelajaran. Hambatan yang dialami kepala sekolah MIN Sukadamai dalam melaksanakan supervisi antara lain adalah sering timbulnya tumpang tindih kegiatan yang harus dilakukan kepala sekolah dalam waktu yang bersamaan, sehingga program yang telah disiapkan kadang-kadang harus ditunda, karena adanya kegiatan lain yang sangat mendesak seperti rapat dinas yang harus didahului. Selanjutnya Upaya yang dilakukan adalah mencari hari lain yaitu jadwal yang tepat untuk pelaksanaan supervisi pendidikan dimaksud. Keterbatasan dana operasional sekolah untuk pembinaan guru, sehingga upaya yang ditempuh adalah melaksanakan pembinaan guru yang seyogyanya dua kali dalam setahun, mengingat 
keterbatasan dana, maka dilaksanakan hanya satu kali dalam setahun. 


\section{DAFTAR PUSTAKA}

Sabandi, A. (2013). Supervisi Pendidikan Untuk Pengembangan Profesionalitas Guru Berkelanjutan. Pedagogi, Jurnal IImiah IImu Pendidikan, 13(2), 1-9. Retrieved from http://ejournal.unp.ac.id/index.php/pedagogi/article/view/4275/3345

Suryani, C. (2016). Implementasi Supervisi Pendidikan Dalam Meningkatkan Proses Pembelajaran Di Min Sukadamai Kota Banda Aceh. Jurnal IImiah Didaktika, 16(1), 23. https://doi.org/10.22373/jid.v16i1.585 